\title{
Measurements of natural radioactivity in soil samples collected in the Kampinoski National Park
}

\author{
Aneta Łukaszek-Chmielewska ${ }^{1}$, Martin Girard ${ }^{1}$, Olga Stawarz ${ }^{2}$, Barbara Piotrowska ${ }^{2}$, \\ Karol Wojtkowski, ${ }^{2,}$, and Krzysztof Isajenko ${ }^{2}$ \\ ${ }^{1}$ The Main School of Fire Service, ul. Słowackiego 52/54, 01-629 Warszawa, Poland \\ ${ }^{2}$ Central Laboratory for Radiological Protection, Department of Dosimetry, ul. Konwaliowa 7, \\ 03-194 Warszawa, Poland
}

\begin{abstract}
In this article are presented the results of measurements of natural radioactivity in twelve soil samples from the Kampinoski National Park by using high purity germanium detector (HPGe). The average values of the natural radionuclides ${ }^{40} \mathrm{~K},{ }^{226} \mathrm{Ra}$ and ${ }^{228} \mathrm{Ac}$ concentrations in the soil samples are 8.54, 6.65 and $206 \mathrm{~Bq} / \mathrm{kg}$ respectively. Additionally radiation hazard indices were calculated to evaluate the radiological risk for the public and environment. The results show that the mean values of radium equivalent activity (Raeq) and gamma absorbed dose rate (D) in the air, outdoor annual effective dose equivalent (Eout), and representative level index $\left(\mathrm{I}_{\gamma}\right)$ for analyzed samples were lower than the limit recommended by the United Nations Scientific Committee on the Effect of Atomic Radiation (UNSCEAR). This study is the first to evaluate the radiological impacts in the investigation area.
\end{abstract}

\section{Introduction}

Ionizing radiation has always been present in human life. It is an integral part of the natural environment. At first, ionizing radiation was coming exclusively from natural sources (described in the literature on natural background radiation) including: cosmic radiation, terrestrial radiation and internal radiation [1].

The intensity of cosmic radiation, mainly coming from the Sun, depends on the height above sea level. The average radiation dose for the general population coming from cosmic rays is $0.33 \mathrm{mSv} /$ year [1].

The main sources of terrestrial radiation are radioactive elements presents in the earth's crust. Among most important ones, we can list uranium $\left({ }^{238} \mathrm{U}\right)$, actinium $\left({ }^{228} \mathrm{Ac}\right)$ and potassium $\left({ }^{40} \mathrm{~K}\right)$ and their decay products. The intensity of terrestrial radiation isn't homogenous around the world. It depends on the geological structure of the region and ranges from $0.3 \mathrm{mSv} / \mathrm{y}$ to $1.5 \mathrm{mSv} / \mathrm{y}$ (average $0.55 \mathrm{mSv} / \mathrm{y}$ ) [1]. There are places on earth

\footnotetext{
* Corresponding author: karol wojtkowski@go2.p1
} 
where the terrestrial radiation is much more intense due to the presence of monazite rocks, which contain high concentration of uranium. The highest natural radiation dose was measured in the mountains of Brazil and reached $120 \mathrm{mSv} /$ year. High natural radiation background doses are also present in the southwest coast of India (due to the presence of monazite sand), in Iran (in Ramsar and Mahallat) as a result of a high concentration of radium in rocks and soils as well as radium in the air, in the US, in Canada and in other countries [1-3].

The next component generating natural radiation background is the internal radiation, whose main source comes from radioactive elements introduced into the body through inhalation(radium and its decay product) or food. Mean value of internal radiation is $0.17 \mathrm{mSv} / \mathrm{y}$ [1].

Scientific studies revealed, that around $99 \%$ of the radioactive precipitations gets stocked in soils [8] because soils act as a buffer accumulating radioactive substances coming from natural sources as well as anthropogenic ones [4]. Studies show, that the mean concentration of radium $\left({ }^{226} \mathrm{Ra}\right)$ in polish soils is $25 \mathrm{~Bq} / \mathrm{lg}$ while the worldwide mean value of ${ }^{226} \mathrm{Ra}$ concentration reaches $35 \mathrm{~Bq} / \mathrm{kg}$. Nevertheless some areas of Poland are also rich in radium including Sudety, Jakuszyce, Szklarska Poręba, Karpacz. The maximum concentration of ${ }^{226} \mathrm{Ra}$ in these areas is $132 \mathrm{~Bq} / \mathrm{kg}$. In the case of potassium $\left({ }^{40} \mathrm{~K}\right)$ isotope, mean value in polish soils and worldwide mean value are very similar, reaching $408 \mathrm{~Bq} / \mathrm{kg}$ for Poland and $400 \mathrm{~Bq} / \mathrm{kg}$ worldwide. The concentration of actinium isotope $\left({ }^{228} \mathrm{Ac}\right)$ is lower in soils of Poland. Mean concentration of this isotope is $23.3 \mathrm{~Bq} / \mathrm{kg}$ for Poland while worldwide mean concentration is $30 \mathrm{~Bq} / \mathrm{kg}$ [5].

Kampinoski National Park (KPN) is a popular region among inhabitants of the Warsaw agglomeration and the localities nearby due to its valuable natural values, numerous patriotic memorials and touristic tracks. No radioactive studies of these soils has been carried out yet. The knowledge of radioactivity level in soils samples will provide people living nearby and visitors of KPN relevant information concerning radiological effects for their health.

\section{Materials and methods}

\subsection{Study area}

Kampinoski National Park (KPN) is of unique natural value, not only for Poland but for the whole Europe. It covers an area of 38544 ha and is situated in the region of the Vistula river valley terraces, in the basin of the Łasica river in the central part of the Warsaw valley extending from Góra Kalwaria to Wyszogród. The area of the Park is made up of: forest land (28219 ha), agricultural land (7805 ha), water (154 ha), ecological land (1484 ha) and other land occupying an area of 886 ha. In 2000, the park together with the protected zone was recognized as biosphere reserve "Puszcza Kampinoska". In 2004, however, the park was classified as a Natura 2000 site. The area of the Park is characterized by the occurrence of parallel bands of dunes areas separated by marshy depressions. It is a typical ice-marginal valley area, which was created by waters flowing into the sea through the wide riverbed of the Prawisła in post-glacial period. KPN surface is composed of quaternary sediments, including: preglacial sands and gravels, boulder clays and water-glacial sediments of three glaciations and river sediments of two interglacial periods, with a thickness of $20 \mathrm{~m}$ to $50 \mathrm{~m}$. Pliocene deposits are formed by compact clays, sandy and silty muds, fine-grained sands and dusty sands that usually form lenses with a small range and thickness [6-12]. 


\subsection{Field sampling}

Soil samples were collected between June and July 2017 from 12 collection points situated in the Kampinoski National Park area. They were collected from a depth of $0-10 \mathrm{~cm}$ using a hand probe. Geographical coordinates of collection points for materials used in further analysis are presented in Table 1 .

Table 1. Geographical coordinates of soil samples collection points in Kampinoski National Park.

\begin{tabular}{|c|c|c|}
\hline Location of samples collection & Longitude & Lattitude \\
\hline Wilcze Śladowskie & $20^{\circ} 18,447^{\prime}$ & $52^{\circ} 21,549^{\prime}$ \\
\hline Bór Kazuński & $20^{\circ} 37,986^{\prime}$ & $52^{\circ} 24,148^{\prime}$ \\
\hline Palmiry - Łomna Las & $20^{\circ} 46,894^{\prime}$ & $52^{\circ} 21,820^{\prime}$ \\
\hline Brzozówka & $20^{\circ} 39,702^{\prime}$ & $52^{\circ} 20,668^{\prime}$ \\
\hline Dziekanów Leśny & $20^{\circ} 50,421^{\prime}$ & $52^{\circ} 20,407^{\prime}$ \\
\hline Famułki Brochowskie & $20^{\circ} 21,469^{\prime}$ & $52^{\circ} 18,627^{\prime}$ \\
\hline Górki & $20^{\circ} 31,347^{\prime}$ & $52^{\circ} 18,700^{\prime}$ \\
\hline Posada Sieraków & $20^{\circ} 47,784^{\prime}$ & $52^{\circ} 19,102^{\prime}$ \\
\hline Granica & $20^{\circ} 26,911^{\prime}$ & $52^{\circ} 17,385^{\prime}$ \\
\hline Julinek & $20^{\circ} 35,720^{\prime}$ & $52^{\circ} 16,676^{\prime}$ \\
\hline Mariewskie Łąki & $20^{\circ} 43,981^{\prime}$ & $52^{\circ} 17,728^{\prime}$ \\
\hline Opaleń & $20^{\circ} 52,267^{\prime}$ & $52^{\circ} 18,179^{\prime}$ \\
\hline
\end{tabular}

\subsection{Laboratory works}

Soil samples were collected with special cylindrical probes with a diameter of $6.9 \mathrm{~cm}$ and a height of $10 \mathrm{~cm}$ as follows: 6 portions from points situated on the perimeter of a circle with a radius of $1 \mathrm{~m}$ and 1 portion from the center of this circle. Then the sample portions were placed in a bag to mix them in order to obtain a homogeneous representation of the given area. In the laboratory, soil samples were dried first at room temperature, then during $16 \mathrm{~h}$ at $105^{\circ} \mathrm{C}$. They were then weighed to get the total mass. Once dried, samples were crushed, sieved through $2 \mathrm{~mm}$ sieves and placed in Marinelli Beakers tightly sealed. The prepared material was then set aside for one month in a safe place to obtain radioactive equilibrium between ${ }^{238} \mathrm{U}$ and ${ }^{228} \mathrm{Ac}$ and their product decays.

Research on soil samples were conducted on a Canberra gamma ray spectrometer. The set consisted of HPGe coaxial detector with an efficiency of $25 \%$ working together with an analyzer, using special software. The measurement time of tested samples was $80000 \mathrm{~s}$. The spectrometer provided a spectrum analysis for gamma ray for photons with energies in the range from 10 to $1800 \mathrm{keV}$. The spectral resolution for ${ }^{60} \mathrm{Co}(\mathrm{E} \gamma=1330 \mathrm{keV})$ is $1.8 \mathrm{keV}$. Detector was placed in a lead protective casing ensuring the reduction by two orders of magnitude of the background coming from external gamma radiation [13]. 


\section{$3 \quad$ Measurements results and analysis}

Measurements of natural radionuclides concentrations in the soils samples were done based on the observed spectral lines and for each sample the concentrations of radionuclide were determined in $\mathrm{Bq} / \mathrm{kg}$ (Table 2).

Table 2. Activity concentrations of natural radionuclides $\left({ }^{40} \mathrm{~K},{ }^{226} \mathrm{Ra}\right.$ and $\left.{ }^{228} \mathrm{Ac}\right)[\mathrm{Bq} / \mathrm{kg}]$ in Kampinoski National Park soil samples.

\begin{tabular}{|c|c|c|c|}
\hline \multirow{2}{*}{ Location of samples collection } & \multicolumn{3}{|c|}{ Activity concentrations $[\mathbf{B q} / \mathbf{k g}]$} \\
\cline { 2 - 4 } & ${ }^{40} \mathbf{K}$ & ${ }^{226} \mathbf{R a}$ & ${ }^{228} \mathbf{A c}$ \\
\hline Wilcze Śladowskie & $188 \pm 7$ & $4.7 \pm 0.5$ & $4.5 \pm 0.2$ \\
\hline Bór Kazuński & $154 \pm 6$ & $7.4 \pm 0.5$ & $5.0 \pm 0.2$ \\
\hline Palmiry - Łomna Las & $140 \pm 5$ & $5.7 \pm 0.5$ & $3.6 \pm 0.2$ \\
\hline Brzozówka & $230 \pm 9$ & $12.6 \pm 0.7$ & $12.0 \pm 0.4$ \\
\hline Dziekanów Leśny & $154 \pm 6$ & $6.9 \pm 0.5$ & $5.1 \pm 0.2$ \\
\hline Famułki Brochowskie & $196 \pm 8$ & $4.8 \pm 0.4$ & $4.2 \pm 0.2$ \\
\hline Górki & $174 \pm 7$ & $6.9 \pm 0.5$ & $4.5 \pm 0.2$ \\
\hline Posada Sieraków & $230 \pm 9$ & $8.3 \pm 0.6$ & $7.0 \pm 0.2$ \\
\hline Granica & $205 \pm 8$ & $9.0 \pm 0.6$ & $6.8 \pm 0.2$ \\
\hline Julinek & $252 \pm 10$ & $10.5 \pm 0.6$ & $8.5 \pm 0.3$ \\
\hline Mariewskie Łąki & $269 \pm 10$ & $9.6 \pm 0.6$ & $7.3 \pm 0.3$ \\
\hline Opaleń & $275 \pm 11$ & $16.1 \pm 0.7$ & $11.2 \pm 0.2$ \\
\hline Mean & $\mathbf{2 0 6} \pm \mathbf{1 3}$ & $\mathbf{8 . 5} \pm \mathbf{1 . 0}$ & $\mathbf{6 . 7 \pm 0 . 8}$ \\
\hline UNSCEAR 2000 [14] & $\mathbf{4 0 0}$ & $\mathbf{3 0 . 0}$ & $\mathbf{3 5 . 0 0}$ \\
\hline & & & \\
\hline & & \\
\hline
\end{tabular}

The highest value of activity of potassium $\left({ }^{40} \mathrm{~K}\right)$ was in Opalen - tourist glade, being equal to $275 \mathrm{~Bq} / \mathrm{kg}$, while the lowest value of activity of ${ }^{40} \mathrm{~K}$ was in Palmiry-Łomna Las, equal to $140 \mathrm{~Bq} / \mathrm{kg}$ with mean value of $206 \mathrm{~Bq} / \mathrm{kg}$. The range of ${ }^{40} \mathrm{~K}$ concentration in Poland is from $45 \mathrm{~Bq} / \mathrm{kg}$ to $1065 \mathrm{~Bq} / \mathrm{kg}$. The present results have shown that values of specific activity of potassium in KPN were less than its recommended value given by UNSCEAR 2000 (equal to $400 \mathrm{~Bq} / \mathrm{kg}$ ) [14, 15]. Mean value of natural potassium in polish soils is equal to $0.68 \%$, while maximum is $2.8 \%$. The highest concentration of this isotope is in places reach in loess and granite like Sudets, Carpathians and North - East Poland [16].

The highest value of concentration of radium $\left({ }^{226} \mathrm{Ra}\right)$ was in Opalen - tourist glade, being equal to $16.06 \mathrm{~Bq} / \mathrm{kg}$, while the lowest value of activity of ${ }^{226} \mathrm{Ra}$ was in Wilcze Śladowskie, equal to $4.74 \mathrm{~Bq} / \mathrm{kg}$ with mean value of $8.54 \mathrm{~Bq} / \mathrm{kg}$. The present results have shown that values of activity of radium in KPN were less than its recommended value given by UNSCEAR 2000 (equal to $30 \mathrm{~Bq} / \mathrm{kg}$ ) $[14,15]$. Radium ${ }^{226} \mathrm{Ra}$ concentration in soil in Poland is in the range of $4.6 \mathrm{~Bq} / \mathrm{kg}$ to $128.0 \mathrm{~Bq} / \mathrm{kg}$ [16]. I normal conditions the content of radium in environment is little and closely related with the content of uranium ${ }^{238} \mathrm{U}$ (parent) Extraction of uranium ores and other minerals, as well as the application of phosphate fertilizers with an increased amount of radium, is the reason for the increase this isotope in soil, in ground and surface water as well as in flora and fauna [16]. 
The highest value of activity of ${ }^{228} \mathrm{Ac}$ was in Brzozówka being equal to $12.03 \mathrm{~Bq} / \mathrm{kg}$, while the lowest value of activity of ${ }^{228} \mathrm{Ac}$ was in Palmiry-Łomna Las, equal to $3.62 \mathrm{~Bq} / \mathrm{kg}$, with mean value of $6.65 \mathrm{~Bq} / \mathrm{kg}$. The present results have shown that values of activity of ${ }^{228} \mathrm{Ac}$ in KPN were less than its recommended value given by UNSCEAR 2000 (equal to $35 \mathrm{~Bq} / \mathrm{kg}$ ) [14, 15].

Furthermore radiological hazards indexes were defined for all the studied soil samples in order to determine the changes in ionizing radiation level and the exposure for humans health resulting from the presence of natural radionuclide in soils.

Table 3 shows values of radium equivalent $\left(\mathrm{Ra}_{\mathrm{eq}}\right)$, level index $\left(\mathrm{I}_{\gamma}\right)$ for soil samples in Kampinoski National Park, absorbed gamma dose rate (D) and outdoor annual effective close equivalent $\left(\mathrm{E}_{\text {out }}\right)$.

Table 3. Values of radium equivalent ( $\mathrm{Ra}_{\mathrm{eq}}$ ), level index $\left(\mathrm{I}_{\gamma}\right)$ for soil samples in Kampinoski National Park, absorbed gamma dose rate (D) and outdoor annual effective dose equivalent (E $E_{\text {out }}$ ).

\begin{tabular}{|c|c|c|c|c|}
\hline \multirow{2}{*}{$\begin{array}{c}\text { Location of samples } \\
\text { collection }\end{array}$} & \multicolumn{4}{|c|}{ Radiological hazards indexes } \\
\cline { 2 - 5 } & Raeq [Bq//kg] & I $\boldsymbol{\gamma}$ [Bq/kg] & D [nGy/h] & $\mathbf{E}_{\mathbf{o u t}}[\mathbf{m S v} / \mathbf{y}]$ \\
\hline Wilcze Śladowskie & 25.65 & 0.10 & 12.91 & 0.016 \\
\hline Bór Kazuński & 26.38 & 0.10 & 12.88 & 0.016 \\
\hline Palmiry - Łomna Las & 21.64 & 0.08 & 10.70 & 0.013 \\
\hline Brzozówka & 47.48 & 0.18 & 22.75 & 0.028 \\
\hline Dziekanów Leśny & 26.06 & 0.10 & 12.75 & 0.016 \\
\hline Famułki Brochowskie & 25.91 & 0.10 & 13.10 & 0.016 \\
\hline Górki & 26.76 & 0.10 & 13.24 & 0.016 \\
\hline Posada Sieraków & 36.07 & 0.14 & 17.82 & 0.022 \\
\hline Granica & 34.49 & 0.13 & 16.89 & 0.021 \\
\hline Julinek & 42.03 & 0.16 & 20.60 & 0.025 \\
\hline Mariewskie Łąki & 40.76 & 0.16 & 20.22 & 0.025 \\
\hline Opaleń & 53.25 & 0.20 & 25.66 & 0.031 \\
\hline Mean & $\mathbf{3 3 . 8 7}$ & $\mathbf{0 . 1 3}$ & $\mathbf{1 6 . 6 3}$ & $\mathbf{0 . 0 2 0}$ \\
\hline UNSCEAR 2000 [14] & $\leq \mathbf{3 7 0}$ & $\leq \mathbf{1}$ & $\mathbf{5 5}$ & $\leq \mathbf{1}$ \\
\hline & & & & \\
\hline
\end{tabular}

On this basis, the obtained values of radiological hazard indexes were analyzed with the reference values determined by the UNSCEAR scientific committee.

Radium equivalent activity index is the most widely used as a radiation hazard index associated with the three radionuclides of ${ }^{40} \mathrm{~K},{ }^{226} \mathrm{Ra}$ and ${ }^{228} \mathrm{Ac}$. $\mathrm{Ra}_{\mathrm{eq}}$ is a weighted sum of activities of these radionuclides based on the estimation that $4810 \mathrm{~Bq} / \mathrm{kg}$ of ${ }^{40} \mathrm{~K}, 370 \mathrm{~Bq} / \mathrm{kg}$ of ${ }^{226} \mathrm{Ra}$ and $259 \mathrm{~Bq} / \mathrm{kg}$ of ${ }^{228} \mathrm{Ac}$ produce the same $\gamma$-ray dose rates. $\mathrm{Ra}_{\mathrm{eq}}$ is given by the following equation [17]:

$$
R a_{e q}\left[\frac{B q}{k g}\right]=A_{R a}+1.43 A_{A c}+0.077 A_{K}
$$

where: $A_{K}, A_{R a}$ and $A_{A c}$ are the activity concentrations $(\mathrm{Bq} / \mathrm{kg})$ of ${ }^{40} \mathrm{~K},{ }^{226} \mathrm{Ra}$ and ${ }^{228} \mathrm{Ac}$. When the value of $R a_{e q}$ is $370 \mathrm{~Bq} / \mathrm{kg}$, this corresponds to $1 \mathrm{mSv} / \mathrm{y}$ [14, 17]. The radium equivalent concept allows a single index or number, which is a widely used hazard index 
to describe the gamma output from different mixtures of potassium, radium and actinium in the soil samples from different locations. The calculated values vary from $21.64 \mathrm{~Bq} / \mathrm{kg}$ (Palmiry-Łomna Las) to $53.25 \mathrm{~Bq} / \mathrm{kg}$ (Opaleń) with mean $33.84 \mathrm{~Bq} / \mathrm{kg}$ (Tab 3.). These values are lower than the permissible maximum value of $370 \mathrm{~Bq} / \mathrm{kg}[14,17]$.

The second one was representative level index $\left(I_{\gamma}\right)$ which is used to estimate the level of gamma radiation hazard.The representative level index must be less than unity to keep the radiation hazard insignificant for the public. The following equation was applied to calculate $\mathrm{I}_{\gamma}$ for soil samples under investigation [18]:

$$
I_{\gamma}\left[\frac{B q}{k g}\right]=\frac{A_{R a}}{300}+\frac{A_{A c}}{200}+\frac{A_{K}}{3000}
$$

where: $A_{K}, A_{R a}$ and $A_{A c}$ are the specific activities of ${ }^{40} \mathrm{~K},{ }^{226} \mathrm{Ra}$ and ${ }^{228} \mathrm{Ac}$ in $\mathrm{Bq} / \mathrm{kg}$, respectively. $I_{\gamma}$ varies from $0.08 \mathrm{~Bq} / \mathrm{kg}$ (Palmiry-Łomna Las) to $0.20 \mathrm{~Bq} / \mathrm{kg}$ (Opaleń) with a mean value of $0.13 \mathrm{~Bq} / \mathrm{kg}$ as shown in Table 3. The values of representative level index for all soil samples was lower than unity $[14,18]$.

The index of the absorbed gamma dose rate $D[\mathrm{nGy} / \mathrm{h}]$ in air at $1 \mathrm{~m}$ above the ground surface for the uniform distribution of radionuclides was calculated based on guidelines provided by $[14,19]$ :

$$
D\left[\frac{n G y}{h}\right]=0.427 A_{R a}+0.623 A_{A e}+0.043 A_{K}
$$

where: $A_{K}, A_{R a}$ and $A_{A c}$ are the activity concentrations $[\mathrm{Bq} / \mathrm{kg}]$ of ${ }^{40} \mathrm{~K},{ }^{226} \mathrm{Ra}$ and ${ }^{228} \mathrm{Ac}$, respectively, in the samples. The absorbed dose rate expresses the received dose in the open air from the radiation emitted from radionuclide concentrations in environmental materials. It is observed that the total absorbed dose rate resulting from ${ }^{40} \mathrm{~K},{ }^{226} \mathrm{Ra}$ and ${ }^{228} \mathrm{Ac}$ ranges between 10.70 Bq/kg (Palmiry-Lomna Las) to $25.66 \mathrm{~Bq} / \mathrm{kg}$ (Opaleń), and the mean value was $16.63 \mathrm{~Bq} / \mathrm{kg}$, which was lower than the limits recommended value of $55 \mathrm{nGy} / \mathrm{h}$ given by the International Commission on Radiological Protection [20, 21].

The outdoor annual effective dose equivalent $\left(E_{\text {out }}\right)$ was calculated from the absorbed dose by applying the dose conversion factor of $0.7 \mathrm{~Sv} / \mathrm{y}$ with an occupancy factor of 0.2 for outdoor $[14,19]$ :

$$
E_{\text {out }}\left[\frac{m S v}{y}\right]=D\left[\frac{n G y}{h}\right] \cdot 8760 h \cdot 0.7\left[\frac{S v}{y}\right] \cdot 0.2 \cdot 10^{-6}
$$

To estimate annual effective doses, conversion coefficient should be taken into account from absorber dose in air to effective dose and the indoor occupancy factor. Based on the present results, values of outdoor annual effective dose equivalent in Kampinoski National Park were less than the recommended value of $1 \mathrm{mSv} / \mathrm{y}$ given by UNSCEAR 2000 [14].

\section{Conclusion}

The natural radioactivity levels of ${ }^{40} \mathrm{~K},{ }^{226} \mathrm{Ra}$ and ${ }^{228} \mathrm{Ac}$ have been measured in soil in Kampinoski National Park using gamma ray spectroscopy. The mean activity concentrations of ${ }^{40} \mathrm{~K},{ }^{226} \mathrm{Ra},{ }^{228} \mathrm{Ac}$ and in soil are $8.54 \mathrm{~Bq} / \mathrm{kg}, 6.65 \mathrm{~Bq} / \mathrm{kg}$ and $206 \mathrm{~Bq} / \mathrm{kg}$. 
The results of the determination parameters such as the radium equivalent activity $\left(R a_{e q}\right)$, representative level index $\left(I_{\gamma}\right)$, absorbed gamma dose rate $(D)$ and outdoor annual effective dose equivalent $\left(E_{\text {out }}\right)$ have been found to be lower than their corresponding allowed limits, hence they will pose relatively no serious health risk.

This work has established background guideline on the natural radioactivity levels in the study area, which will provide a future reference for other studies.

\section{References}

1. A. Kuliczkowski, R. Pluta, D. Zwierzchowski, MŚRŚ 1, 47-50 (1993)

2. L. A. Najam, H. L. Mansour, N. F. Tawfiq, M. S. Karim, JRN, Appl. 1, 25-30 (2016)

3. A. G. E. Abbady, M. A. Adel, A.El-.Taher, JER 84, 1, 65-78 (2005)

4. S. Wołkowicz, R. Strzelecki, PG 50, 10/2 (2002)

5. Mirosław Janik, Shinji Tokonami, Jpn. JHP 44, 1, 116-121 (2009)

6. A. Andrzejewska, Monitoring wód powierzchniowych $i$ podziemnych KPN ([w:] M. Sosnkowski, B. Gołecki (red.). Raport o stanie środowiska w województwie stołecznym warszawskim w 1996 roku, BMŚ, 1996)

7. A. Andrzejewska, Klimat Puszczy Kampinoskiej ([w:] R. Andrzejewski (red.), KPN, 1, 41-68, 2003)

8. A. Andrzejewska, PK 3, 8-11 (2008)

9. R. Andrzejewski, PK 2, 231-239 (2004)

10. S. Borek, Niektóre właściwości fizyczne gleb Rezerwatu Granic w Kampinoskim Parku Narodowym, (1983)

11. K. Konecka-Betley, Wpływ działalności człowieka na środowisko glebowe w Kampinoskim Parku Narodowym (IG SGGW-AR, KGiChR PAN, Warszawa, 1983)

12. T. J. Chmielewski, Operat generalny planu ochrony Kampinoskiego Parku Narodowego ([w:] Plan Ochrony Kampinoskiego Parku Narodowego, NFOŚ, Warszawa, 1996)

13. K. Konecka-Betley, Geneza gleb Kampinoskiego Parku Narodowego ([w:] B. Dobrzyński, K. Konecka-Betley (red.) Wptyw działalności człowieka na środowisko glebowe w Kampinoskim Parku Narodowym, Instytut Gleboznawstwa SGGW-AR, KGiChR PAN, Warszawa, 1983)

14. K. Isajenko, B. Piotrowska, O. Stawarz, A. Łukaszek-Chmielewska, S. Krawczyńska, BiTP 46, 2 (2017)

15. United Nations Scientific Committee on the Effects of Atomic Radiation (UNSCEAR) Sources, ERIR, New York, United Nations (2000)

16. M. Abusini, K. Al-ayasreh, J. Al-Jundi, RPD 128, 2, 213-216 (2003)

17. K. Isajenko, M. Fujak, B. Piotrowska, Monitoring stężenia ${ }^{137} \mathrm{Cs} w$ glebie $w$ latach 2012-2013 (2014)

18. H. M Dia, S. A. Nouh, A. Hamdy, S. A. EL-Fiki, NRP 3, 1, 53-62 (2008)

19. A. Al-Taher, S. Makhluf, Upper Egypt, IJP \& AP 48, 697-702 (2010)

20. S. Sherif, D. Al-Othmany, H. Q. Hamidalddin, J. H. Al-Zahrani, W. R. Alharbi, H. M. Barashed, JGEP 5, 66-75 (2017)

21. A. M. El-Arabi, IJP \& AP 43, 422-426 (2005) 